1973

\title{
Admiralty and Maritime Law
}

\author{
Various Editors
}

Follow this and additional works at: https://digitalcommons.law.villanova.edu/vlr

Part of the Admiralty Commons, Conflict of Laws Commons, and the Courts Commons

\section{Recommended Citation}

Various Editors, Admiralty and Maritime Law, 19 Vill. L. Rev. 281 (1973).

Available at: https://digitalcommons.law.villanova.edu/vlr/vol19/iss2/4

This Issues in the Third Circuit is brought to you for free and open access by Villanova University Charles Widger School of Law Digital Repository. It has been accepted for inclusion in Villanova Law Review by an authorized editor of Villanova University Charles Widger School of Law Digital Repository. 


\title{
Admiralty and Maritime Law
}

\author{
ADMiralTy - Jurisdiction - Admiralty Court Has Exclusive \\ JURISDiction OVER the Distribution of a Limitation of Liability \\ Settlement Fund in its Registry.
}

In re Central R.R. of N.J. (3d Cir. 1972)

The Santa Isabel, a vessel owned by Grace Line, Inc., rammed and damaged a drawbridge owned by the New York and Long Branch Railroad (Long Branch) in March 1966..$^{1}$ Grace Line promptly filed a petition in admiralty to limit its liability for damages arising out of the accident. ${ }^{2}$ In May 1966, Long Branch and its co-owners, the Central Railroad Co. of New Jersey (Central) and the Pennsylvania Railroad (PRR), filed a claim in the admiralty court against Grace Line for damages. Late in 1969, that court permitted limitation of liability and accepted the settlement figure that had been agreed on by the Grace Line and the three railroads. ${ }^{3}$ The admiralty court ordered that amount placed in its registry while it considered how the fund was to be allocated.

In March 1967, while its claim against Grace Line was still pending in the admiralty court, Central filed a petition for reorganization. ${ }^{4}$ The reorganization court subsequently disagreed with the proposed division of the settlement fund in the admiralty registry, ${ }^{5}$ and in October 1970 issued an order which, in effect, directed how certain of the funds in that registry

1. The drawbridge was part of the 39.96 miles of track owned by Long Branch R.R. Long Branch in turn was owned in equal shares by the Central Railroad Co. of New Jersey (Central) and the Pennsylvania Railroad (PRR) which had joint use of its tracks and facilities under a 999 year agreement entered into in 1930: In re Central R.R. of N.J., 469 F.2d 857, 858 (3d Cir. 1972).

2. Grace Line filed the petition in the United States District Court for the Southern District of New York. Id. Limitation of liability is controlled by 46 U.S.C. $\$ \$ 181-96(1970)$.

3. Grace Line's liability was limited to $\$ 1,500,000$. According to the settlement's proposed allocation, PRR was to receive $\$ 834,251.02, \$ 740,482.95$ of which represented reimbursement for expenses, $\$ 84,889.94$ consequential damages, and $\$ 8,878.13$ interest; Central was to receive $\$ 205,748.98$ as reimbursement for consequential damages: and Long Branch was to receive nothing. The proposed allocation also provided $\$ 110,000.00$ for counsel fees. 469 F.2d at 859 .

4. This petition was filed in the United States District Court for the District of New Jersey pursuant to the Railroad Reorganization Act, 11 U.S.C. § 205 et seg. (1970). 469 F.2d at 859.

5. Since, at the time of the accident, Central's cash position had prevented it from advancing its 50 per cent share of the emergency expenses incurred by Long Branch, PRR had advanced the full amount of $\$ 740,482.95$. 469 F.2d at 858. Under the terms of the settlement's proposed allocation this amount was to be repaid to PRR in full. Id. at 859 . The reorganization court found that PRR was entitled to only one-half that amount - the $\$ 370,241.48$ PRR had advanced on its own behalf As to the other $\$ 370,241.48$, the reorganization court viewed $P R R$ as an unsecured 
were to be allocated. ${ }^{\circ}$ Since the reorganization court's division of the settlement proceeds would have resulted in the PRR receiving a sum over $\$ 370,000$ less than it was to have received under the terms of the proposed admiralty allocation, ${ }^{7}$ the PRR's successor, the Penn Central Transportation Company $^{8}$ (Penn Central) appealed from the order. The Third Circuit reversed the decision of the reorganization court, holding that the admiralty court had exclusive jurisdiction over the distribution of the limitation of liability settlement fund in its registry, and that the reorganization court was without jurisdiction to adjudicate the rights of the claimants to that fund. In re Central R.R. of N.J., 469 F.2d 857 (3d Cir. 1972).

The Constitution delegates admiralty and maritime jurisdiction to the federal government. ${ }^{9}$ Pursuant to that power, in 1851 Congress enacted a statute to allow a shipowner to limit his liability for tort claims against his vessels. ${ }^{10}$ The act was designed to encourage the development of American shipping by allowing the shipowner to place a ceiling on the amount of damages arising out of any one accident for which he could be held liable. ${ }^{11}$ The statute confers jurisdiction on the fecleral district courts generally ${ }^{12}$ and the Supreme Court, exercising its rule-making power, has assigned exclusive jurisdiction in limitation actions to the admiralty courts. ${ }^{13}$

Bankruptcy and reorganization jurisdiction is also granted to the federal government by the Constitution, ${ }^{14}$ although federal bankruptcy law did not substantially develop until $1898 .{ }^{15}$ Railroad reorganization in par-

6. Order No. 368, October 13,1970 . The trustee of Central was ordered, inter alia, to withdraw $\$ 370,241.48$, plus a sum representing PRR's share of the consequential damages, from the admiralty court's registry and to pay it to the PRR. The trustee was instructed to take "appropriate action" to obtain the balance for the debtor. 469 F.2d at 860 .

7. See note 5 supra.

8. The Penn Central was created by the February 1968 merger of the PRR with the New York Central R.R. Penn Central petitioned for reorganization in June 1970. 469 F.2d at 858 n.1.

9. U.S. Const. art. III, § 2. The constitutional grant is exclusively federal. 1 E. Benedict, The Law of American Admiralty $\& 1$ (6th ed. 1940).

10. Act of March 3, 1851, ch. 43, § 3, 9 Stat. 635, as amended 46 U.S.C. $\$ 183$ (1970). The procedure for limitation of liability is presently regulated by FED. R. Civ. P. Supr. R.F., formerly General Admiralty Rules 51-54, 334 U.S. 864 (1948).

11. For a discussion of the history and development of shipowner limitation of liability, see 3 E. BENEDICr, supra note 9, \$\$ 474-78, 541-44; Eyer, Shipowner's Limitation of Liability - New Directions for an Old Doctrine, 16 STAN. L. REv. 370 (1964).

The right to limit liability has been extended to shipowners whose vessels have been involved in accidents with structures attached to land. Richardson $v$. Harmon, 222 U.S. 96 (1911). Such accidents historically did not fall within admiralty jurisdiction. Sce 1 E. BENEDICT, supra note 9, \& 101 (Supp. 1972).

12. See 46 U.S.C. $\$ 185$ (1970).

13. The Court first issued its rules governing the practice in limitation proceedings in 1872. Supplemental Rules of Practice in Admiralty 54-57, 80 U.S. (13 Wall.) xii-xiv.

14. U.S. Const. art. I, $\S 8$, cl. 4. 
ticular is governed by the Railroad Reorganization Act, ${ }^{16}$ which provides that during the reorganization proceedings ${ }^{17}$ the reorganization court has "exclusive jurisdiction over the debtor and its property wherever located."18 This extensive grant of jurisdiction was designed to correct some of the inefficiencies encountered under the earlier system of equity receiverships in which courts often found themselves handicapped by a lack of jurisdictional power and could not effectively administer and control all aspects .of the debtor's estate. ${ }^{19}$ The jurisdictional grant is not all-inclusive, however, since questions of whether or not certain "property" actually belongs to the debtor may have to be settled by other courts. ${ }^{20}$

In the instant case, the majority did not hesitate in limiting the reorganization court's power over the debtor's "property." The court defined the issue as being whether or not the admiralty court's jurisdiction was exclusive as to the disposition among claimants ${ }^{21}$ of a fund in its possession due to settlement of a limitation of liability proceeding, ${ }^{22}$ and answered the question in the affirmative. ${ }^{23}$ The court stressed the fact that the admiralty court had specifically directed that this fund was subject to its continuing control, ${ }^{24}$ and that in spite of that decision the reorganization court had attempted to determine the legal rights of Central and PRR in the sum. ${ }^{25}$ The court rejected this attempted usurpation of the admiralty court's power, asserting that it had been "long settled" that, once jurisdiction was acquired by an admiralty court in a limitation of liability proceeding in which the claims $^{26}$ exceeded the value of the vessel plus freight, the jurisdiction

16. 11 U.S.C. $\S 205$ et seq. (1970). For a general analysis and history of the legislative development of this statute, see $5 \mathrm{~W}$. ColliER, supra note 15, I 77.02, at $466.4-73$.

17. Reorganization procedure is designed to make the debtor sound while fairly adjusting the legal rights of the debtor's creditors and shareholders. $6 \mathrm{~W}$. Collier, supro note $15, \pi 0.01$, at 2 .

18. 11 U.S.C. $\$ 205(\mathrm{a})(1970)$.

19. $6 \mathrm{~W}$. Collier, supra note 15, If 3.07, at 460-63. For a description of how the reorganization plan is implemented, see 2 id. $\Uparrow 77.02$, at $472-73$.

20. It should be noted, when considering the decision in the instant case, that the Third Circuit has adopted an expansive definition as to what could be considered the "property" of the debtor for jurisdictional purposes, and has affirmed the power of a reorganization court to enjoin any action that would impair the property or assets of the debtor, even though that "property" lay outside of the court's territorial jurisdiction and the question of ownership was very much in dispute. See In re International Power Sec. Corp., 170 F.2d 399 (3d Cir. 1948).

21. The court was inconsistent in its characterization of the railroads' claim. See note 38 infra.

22. 469 F.2d at 861.

23. $I d$.

24. Id. at 863 . The majority noted that the reorganization court had not discussed the question of its own jurisdiction and seemed particularly troubled by the summary nature of the action taken by that court. Id.

25. Id. at 860-61. The court emphasized the fact that the reorganization court had "adjudicated" the rights of the various claimants to a fund in an admiralty

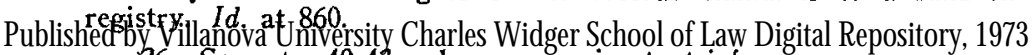


was exclusive. ${ }^{27}$ Thus, for the majority, the solution was clear; the admiralty court had the fund in its registry and its jurisdiction was exclusive, therefore the reorganization court completely lacked the power to issue any orders affecting the fund.

Judge Adams, dissenting in part and concurring in part, ${ }^{28}$ did not think that the issues raised in the case could be disposed of so simply. ${ }^{29}$ Unlike the majority, he recognized and discussed the jurisdictional basis for the reorganization court's order, ${ }^{30}$ and could not agree that the reorganization. court lacked jurisdiction. ${ }^{31}$ Since Judge Adams did not consider that precedent required the court to vacate the order of the reorganization court on. jurisdictional grounds, ${ }^{32}$ he was free to adopt a functional approach to the issues, as opposed to the more formalistic one adopted by the majority. After examining the purposes and functions of the limitation of liability and the reorganization statutes, ${ }^{33}$ he concluded that the congressional purpose behind the grant of extensive jurisdiction to the admiralty courts would not be aided by the decision reached by the court, ${ }^{34}$ and that the majority's decision would defeat the purpose behind the broad congressional. delegation of power to the reorganization courts. ${ }^{35}$ Judge Adams therefore considered that the jurisdictional conflict should have been resolved in. favor of the reorganization court. ${ }^{36}$

It is notable that the majority chose to base its decision on a broad. reading of the admiralty court's powers in a limitation of liability proceeding, for it is submitted that the court had the alternative of approaching the situation in the same functional manner as Judge Adams did. The

27. 469 F.2d at 861 . The majority relied on a series of Supreme Court cases involving multiple claimants. Id. at 861-62. Judge Adams pointed out, however, that here there was "essentially" a single claimant and that the policy of avoiding a multiplicity of suits was therefore not relevant. Id. at 869 (dissenting opinion).

28. The majority, after deciding that the reorganization court lacked jurisdiction, went on to conclude that that court was incorrect in its assumption that Central had agreed to any "overriding obligation" to repay PRR. Id. at 863. Judge Adams agreed with the latter conclusion but dissented on the jurisdictional aspects of the court's decision. Id. at 871 (dissenting opinion).

29. Id. at $871 \mathrm{n} .12$ (dissenting opinion). In Judge Adams' view the court's task was to reconcile the two statutes, not to resort to a "mechanical rule" to resolve the conflict. Id. at 867 (dissenting opinion).

30. Id. at 869-71 (dissenting opinion).

31. Id. at $865,867,871$ (dissenting opinion).

32. Id. at 869 (dissenting opinion).

33. Id. at 867-69 (dissenting opinion).

34. Id. at 869,871 (dissenting opinion).

35. Id. at 871 (dissenting opinion).

36. Judge Adams pointed out the reorganization court's decision did not effect the "primary functions" of the admiralty court - limiting liability and deciding negligence. Id. at $871 \mathrm{n} .11$ (dissenting opinion). His "functional" approach is illustrated by his concession that, under "usual circumstances," the admiralty court should decide the allocation. Id. at 869 (dissenting opinion). What presumably made this instance "unusual" was the availability of the reorganization court's expertise, an 
cases cited by the majority ${ }^{37}$ to justify its conclusion that the admiralty court's jurisdiction was exclusive are all arguably distinguishable from the instant case in that they all involved multiple claimants. While neither the majority nor Judge Adams was particularly clear on this point, ${ }^{38}$ it would seem entirely possible to characterize the petition of Central, PRR, and Long Branch as being a "single claim," 39 and thus bring this case, at least by analogy, under a well recognized "single claimant" exception to the exclusive jurisdiction rule in limitation of liability cases.

The "single claimant" exception is based on a desire to accommodate the shipowner's right to petition in admiralty to limit his liability with the plaintiff's right to pursue his remedies in a common law court. ${ }^{40}$ The exception, recognized by the Supreme Court in two decisions in the early 1930 's, ${ }^{41}$ allows the single claimant to litigate the issue of shipowner liability in a non-admiralty forum so long as the admiralty court retains exclusive jurisdiction over the limitation question. ${ }^{42}$ If a transfer of the

37. Maryland Cas. Co. v. Cushing, 347 U.S. 409 (1954); Just v. Chambers, 312 U.S. 383 (1941); Hartford Accident \& Indem. Co. v. Southern Pac. Co., 273 U.S. 207 (1927); Providence \& N.Y. S.S. Co. v. Hill Mfg. Co., 109 U.S. 578 (1883).

38. The majority initially noted that the three railroads filed " 2 claim." 469 F.2d at 859 . However, "claim" was usually used by the majority in its plural form and the admiralty cases cited all involved multiple claims. See notes $39-43$ and accompanying text infra. The majority apparently did not see any significance in the possible distinction between singular and plural plaintiffs.

Judge Adams was clearly willing to view this as a single claim. See 469 F.2d at 867,869 (dissenting opinion). It is submitted that the court could have used this distinction as a basis for the proposition that the jurisdiction of the admiralty court was not exclusive. See note 43 infra.

Curiously, the court, in dicta, observed that Long Branch was the claimant that alone could be compensated. 469 F.2d at 865 . Presumably this supports the position that the reorganization court should not have adjudicated the allocation of funds due Long Branch. However, the opposite conclusion might also be reached, i.e., that the admiralty court's interest ceased once it was established that Long Branch was entitled to the fund, and that the division of the fund among the co-owners of Long Branch might well be left to the reorganization court.

39. For examples of "single claims," see In re Republic of (S.) Korea, 175 F. Supp. 732, 735 (D. Ore. 1959) (seaman's suit carried with it a potential claim for indemnification on the part of the ship's agent); In re M. P. Howlett, Inc., 75 F. Supp. 438, 439 (E.D.N.Y. 1948) (plaintiff's insurer also had a claim for money it had advanced).

40. The policies that underlie the grant of exclusive jurisdiction to the admiralty court in the multiple claimant-limited fund situation - avoiding multiple suits and conflicting verdicts - do not apply where there is a single claim. See G. GrLmore \& C. Black, The Law of Admiralty \& 10-19 (1957).

41. Ex parte Green, 286 U.S. 437 (1932); Langes v. Green, 282 U.S. 531 (1931).

42. Ex parte Green, 286 U.S. 437, 439-40; Langes v. Green, 282 U.S. 531, 541-42. A plaintiff has a traditional right to a common law remedy under the "saving to suitors" clause of the Judiciary Act of 1789, ch. $20, \S 9,1$ Stat. 76, as amended, 28 U.S.C. $\& 1333(1970)$. Under the "single claimant" exception limitation is decided in the admiralty court and liability in the state court; the "rights of both parties" are preserved. 282 U.S. at 541 . For a further discussion sre H. BAER, Admiralty Law of the Supreme Court $\S 10-4$ (2d ed. 1969); 3 E. Benedict, supra note $9, \S 491$.

Since the Green case, the "single claimant" rule of comity with a nonadmiralty forum has been followed by several circuits. See Famiano v. Enyeart, 398 F.2d 661 (7th Cir. 1968): George J. Waldie Towing Co. v. Ricca, 227 F.2d 900 (2d Cir. 1955); The Helen R., 109 F.2d 884 (9th Cir. 1940). The view expressed by Judge Adams in the instant case would seem to be more consistent with the 
authority to decide liability is permissible, it would then seem that the court's holding as to the exclusivity of the admiralty jurisdiction in the instant case was not as obvious a conclusion as the majority deemed it to be. ${ }^{43}$ If this is so, then it would have been possible for the majority to do that which it did not do - recognize and directly address the problem of achieving some reconciliation of the conflict between the admiralty and reorganization jurisdictions.

While conceding the appropriateness of the admiralty court's jurisdiction in regard to the issues of liability and limitation, ${ }^{44}$ Judge Adams found little merit in retaining control of the allocation in that forum, ${ }^{45}$ since, as he contended, the admiralty court did not even address the merits of the settlement which it approved. ${ }^{46}$ However, while Judge Adams' arguments for a "symbiosis" of the two statutes may be persuasive in terms of economy in the allocation of judicial resources, any implementation of the reorganization court's order would require an extension of the jurisdictional power of the reorganization court. ${ }^{47}$ While the Third Circuit has been expansive in its approach toward reorganization jurisdiction in the past, ${ }^{48}$ a limit traditionally has been placed on the reorganization court's power where the property in question is not in the debtor's possession and is subject to a bona fide adverse claim. ${ }^{49}$ In such a case the procedure is usually a plenary action wherein the trustee of the debtor sues to gain possession of the property. ${ }^{50}$ The reorganization court's attempt to assert control over the fund in the admiralty court's registry without resort to plenary process would thus appear to be improper.

Although the reorganization court's attempt to control the disposition of the fund may justifiably be criticized, it is not at all clear why, especially in light of Judge Adams' argument based on the disparate functions and capabilities of the two courts, the reorganization court should be completely deprived of any opportunity to attempt such an allocation. While

43. It is submitted that the court could have characterized the case as one involving a single claim. The delegation of authority in the single claimant cases could then have served as precedent for the proposition that the admiralty court's jurisdiction need not be exclusive in the instant situation, and the majority could have approached the merits of the argument for allowing the reorganization court to settle the allocation question. The "comity" analysis adopted in Green would also seem germane.

44. 469 F.2d at 866 (dissenting opinion).

45. Id. at 871 (dissenting opinion). See note 36 supra.

46. 469 F.2d at 866 (dissenting opinion).

47. See $6 \mathrm{~W}$. Collier, supra note 18 , i 3.05 , at 448 ; id. 73.07 , at 466 . Where property is held by a bona fide claimant outside of the territorial jurisdiction of the reorganization court, resort to summary process is normally not permitted. Id. If 3.07 , at 466 .

48. See cases cited in 469 F.2d at $869-70$ (dissenting opinion). While none of these cases involved as formidable a challenge to the reorganization power as was posed here by the presence of the "property" in the admiralty registry, they would support a broad interpretation of the extent of the reorganization court's jurisdiction. One might presume from the majority's silence on this subject that the court did not find Judge Adams' argument persuasive. See also note 20 and acompanying text supra. 
a close reading of the majority's opinion might not require such a conclusion, ${ }^{51}$ it is not at all clear that that was not, in fact, what the court meant. ${ }^{52}$ Unfortunately, there is no discussion of this possibility in the opinion.

The court, instead of analyzing the limitations that exist on the expansion of reorganization jurisdiction, chose to emphasize the traditional control admiralty courts retain over limitation of liability actions. While strongly affirming the power inherent in the limitation of liability proceeding, the court turned away from a rare opportunity for a thoughtful analysis of the relative parameters of the reorganization and admiralty jurisdictions.

$$
\text { A. A. G. }
$$

\section{ADMIRALTY - Warranty of Seaworthiness - Warranty to a Seaman Does Not Include Obligation to Furnish a Reason- ably Safe Place to Work.}

Earles v. Union Barge Line Corp. (3d Cir. 1973)

Employees of an independent contractor brought suit against a barge owner for a breach of the warranty of seaworthiness for injuries sustained from breathing poisonous fumes in the course of cleaning the barge. ${ }^{1}$ The vessel had been discharged of poisonous chemical cargo prior to its delivery to plaintiffs' employer who had contracted with the barge owner to strip, wash, and pump the barge clean. ${ }^{2}$ Plaintiffs entered one of the barge's tanks to clean it, without knowledge of the poisonous cargo or fumes, and were quickly overcome. ${ }^{3}$ A jury trial in the United States District Court for the Western District of Pennsylvania on the issue of unseaworthiness resulted in verdicts for the employees. ${ }^{4}$ On appeal, the Third Circuit reversed, holding that it was error for the trial court to charge

51. The majority seemed as disturbed by the manner in which the reorganization court asserted its power as by the assertion of power itself. See notes $24 \& 25$ and accompanying text supra. A narrow reading of the opinion might support the conclusion that if the reorganization court had gained control of the fund by less pre-emptive means - if it had requested the fund rather than demanded it, and the admiralty court had agreed - the reorganization court might have been allowed to allocate the fund on the basis of its obvious interest and expertise.

52. A broad reading of the majority opinion would justify a conclusion that once the settlement fund came within the control of the admiralty forum, all questions as to allocation had to be settled by it. This could be supported by stressing the word "shall" in FED. R. CIV. P. SuPP. R. F. (8), cited by the majority as authority for the proposition that there was no need for the reorganization court to consider the objections other creditors had to the admiralty settlement allocation, since the alternative of a hearing in the admiralty forum was always available. 469 F.2d at $862-63$.

1. Earles v. Union Barge Line Corp., 321 F. Supp. 1329 (W.D. Pa. 1970).

2. Earles v. Union Barge Line Corp. 486 F.2d 1097 , 1099 (3d Cir. 1973). 
that the warranty of seaworthiness includes the duty to provide a reasonably safe place for a seaman to work. Earles v. Union Barge Line Corp., 486 F.2d 1097 (3d Cir. 1973).

There has been no clear and consistent line of demarcation between liability for negligence and liability for unseaworthiness in admiralty law." Historically a seaman could not recover from a shipowner for injuries resulting from negligence. ${ }^{6}$ However, in 1903, the Supreme Court moved away from that general proposition in The Osceola, ${ }^{7}$ wherein the Court, while denying recovery for negligence, held a shipowner liable for the personal injuries of a seaman when negligence rendered the vessel unseaworthy. ${ }^{8}$ Thus, after The Osceola, liability for unseaworthiness was predicated upon the shipowner's lack of reasonable care. ${ }^{\circ}$ In Mahnich $v$. Southern Steamship Co. ${ }^{10}$ the Court shifted its position and, looking to dictum in Carlisle Packing Co. $v$. Sandanger, ${ }^{11}$ characterized the shipowner's duty as an absolute warranty - a liability which would not be relieved by the exercise of due care, and, therefore, not predicated on negligence. ${ }^{12}$ Breach of the warranty of seaworthiness owed by shipowner to seaman, ${ }^{13}$ which was a proximate cause of injuries, gave rise to strict liability.

In Mitchell $v$. Trawler Racer, Inc., ${ }^{14}$ the Supreme Court, considering the question of whether, with respect to "transitory" unseaworthiness, liability was limited by concepts of negligence, emphasized the independence of the two concepts, ${ }^{15}$ and focused on the scope of the warranty of seaworthiness. The warranty consists of an absolute duty "to furnish a vessel and appurtenances reasonably fit for their intended use."16 For liability

5. For a discussion of the origin and history of mariners' remedies for injuries in general and injuries resulting from unseaworthiness of the vessel, see Tetreault, Seamen, Seazorthiness and the Rights of Harbor Workers, 39 CoRNell L.Q. 381 (1954). For a review of the doctrine of unseaworthiness in personal injury cases as developed by the Supreme Court, see Mitchell v. Trawler Racer, Inc., 362 U.S. 539 (1960); Mahnich v. Southern S.S. Co., 321 U.S. 96 (1944).

6. Tetreault, sipra note 5 , at 385,392 .

7. 189 U.S. 158 (1903).

8. Id. at 175 .

9. Tetreault, supra note 5 , at 392 .

10. 321 U.S. 96 (1944).

11. 259 U.S. 255 (1922). In Carlisle Packing, the shipowner was found negligent, but the view was expressed that there could be liability for unseaworthiness without regard to negligence.

12. 321 U.S. at 100 .

13. The Court applied the warranty to employees of independent contractors in Seas Shipping Co. v. Sieracki, 328 U.S. 85 (1946). Subsequently, the Court refused to limit the Sieracki holding to longshoremen and allowed a carpenter doing repairs to recover against the shipowner. Pope \& Talbot, Inc. v. Hawn, 346 U.S. 406 (1953). Congress, however, has eliminated the warranty of seaworthiness with respect to those employees covered by the Longshoremen's and Harbor Workers' Compensation Act. 33 U.S.C. $\S 905$ (b) (Supp. II, 1972). For a discussion of the elimination of the warranty and longshoremen's remedies for personal iniuries in general, see Note, Maritime Jurisdiction and Longshoremen's Remedies, 1973 WASF. U.L.Q. 649.

14. 362 U.S. 539 (1960).

15. While the two concepts are separate, and while unseaworthiness is not dependent upon negligence, negligence can result in unseaworthiness. See Usner v. 
to attach there must be a condition ${ }^{17}$ which causes injury to a seaman. It is not necessary that the vessel owner be aware of the condition $;^{13}$ the condition may be outside the owner's control $;^{19}$ and, it may be temporary as well as permanent. ${ }^{20}$ The Supreme Court appeared to be consistently expanding liability for unseaworthiness until its decision in Usner $\%$ Luckenbach Overseas Corp. ${ }^{23}$. wherein it distinguished a single negligent act of a third party from an unseaworthy condition and concluded that operational negligence does not necessarily constitute instant unseaworthiness. ${ }^{22}$

In the instant case, the barge owner contended as a matter of law that the barge was not unseaworthy. ${ }^{23}$ The court, looking to prior cases in the Second ${ }^{24}$ and Fifth Circuits, ${ }^{25}$ as well as its own, ${ }^{26}$ which had held noxious fumes in a ship's hold to have created an unseaworthy condition, flatly rejected that argument. ${ }^{27}$ The court concluded that had the jury been correctly charged on the law of unseaworthiness it would have had no reason to disturb the verdict for the plaintiffs. ${ }^{28}$ However, the trial court had charged:

A ship owner's warranty of seaworthiness includes furnishing a reasonably safe place for a seaman or one working aboard the barge to perform his chores. ${ }^{20}$

The court of appeals found the charge to be reversible error. ${ }^{30}$ The lower court, it concluded, had mistakenly confused and combined concepts which

17. As noted by the Earles court, "where there is no defective condition of the equipment, appurtenances, crew, cargo, or gear of the ship, then no liability for unseaworthiness can exist." 486 F.2d at 1102-03. For a discussion of the expansion of the definition of a "condition," see 17 VILL. L. REv. 130, 132-34 (1971).

18. 362 U.S. at 549.

19. Id.

20. In Mitchell, for example, the defective condition was slime on a railing. $I d$. at 540 .

21. 400 U.S. 494 (1971).

22. Id. at 500 . Usner held that one unforeseeable act of negligence by a fellow longshoreman does not result in liability for unseaworthiness. Id.

23. 486 F.2d at 1103 .

24. Albanese v. N.V. Nederl. Amerik Stoomv. Maats, 346 F.2d 481 (2d Cir.), rev'd on other grounds, 382 U.S. 283 (1965).

25. Grigsby v. Coastal Marine Serv. of Tex., Inc., 412 F.2d 1011 (5th Cir. 1969), petition for cert. dismissed, 396 U.S. 1033 (1970).

26. Jones v. Den Norske Amerikalinje A/S, 451 F.2d 985 (3d Cir. 1971). In Jones, the court followed the Albanese theory of unseaworthiness and approved recovery on that basis by a longshoreman who had sustained injuries from breathing carbon monoxide in the ship's hold.

27. 486 F.2d at 1103 . The court noted that had the employer known that it was being hired to remove poisonous fumes and had the plaintiffs been told, then recovery could not be had on the basis of unseaworthiness. Id. at 1104. "[T] here is no warranty that the vessel is seaworthy with respect to the unseaworthy condition which is directly responsible for bringing aboard the persons claiming the benefit of the warranty." Id., quoting Grigsby v. Coastal Marine Serv. of Tex., Inc., 412 F.2d 1011, 1030 (5th Cir. 1969). However, no evidence had been introduced at trial concerning knowledge of the fumes on the part of either the employer or barge owner. 486 F.2d at 1104 . 
belonged to the law of negligence with the strict liability of the warranty of seaworthiness.

The duty to provide a reasonably safe place to work was characterized by the court of appeals as a duty of care, the breach of which, if the proximate cause of injury, gives rise to liability for negligence. ${ }^{31}$ The Supreme Court had "clearly and repeatedly" stated that the shipowner's duty to provide a seaworthy vessel was not dependent upon concepts of negligence - liability under the two concepts was wholly distinct. ${ }^{32}$ Therefore, the court reasoned, even though the same occurrence could conceivably breach both duties, a breach of one did not necessarily result in a breach of the other. As the court noted, whether the barge was unseaworthy depended entirely upon whether it was reasonably fit for the purpose for which it was to be used and not upon the barge owner's negligence. ${ }^{33}$ To charge, in effect, that liability for unseaworthiness would result in all cases from the shipowner's negligence was error ${ }^{34}$

The opinion in Earles appears clear and well reasoned. While one might argue that the duty to provide a reasonably safe place to work does not appear so different from the duty to provide equipment reasonably suited for its intended use that the two should be separated, ${ }^{35}$ they are two

31. The court stated that the duty was "clearly a duty of care." Id. at 1104 (emphasis added). Given the distinction the Supreme Court has drawn between the concepts of unseaworthiness and negligence, such a characterization would appear to "put the rabbit in the hat." If the duty is clearly a duty of care, breach of which may give rise to liability for negligence, and if unseaworthiness is distinct from negligence, then, although action which would breach a duty of care might also, under certain circumstances, breach the warranty of seaworthiness, a charge which, in effect, states that mere breach of a duty of care must be a breach of the warranty is clearly erroneous. The court, however, did not rest on its bare characterization of the duty to support its position. It looked to the language in three Supreme Court cases which indicated that the duty to provide a reasonably safe place to work belonged to the law of negligence. Id. at 1104-05.

32. The court cited and quoted both Usner v. Luckenbach Overseas Corp., 400 U.S. 494 (1971), and Mitchell v. Trawler Racer, Inc., 362 U.S. 539 (1960), as support for its conclusion that the concepts should be treated separately, and stated:

The Court has not melded the duty to provide a seaworthy vessel with the duty to provide a reasonably safe place to work, but has repeatedly stated that the two concepts of seaworthiness and negligence should remain separate and distinct. 486 F.2d at 1105 .

33. 486 F.2d at 1107.

34. The case was remanded for a new trial. Although the court did not expressly so state, it would appear that the charge to the jury at the new trial should omit any reference to a duty to provide a reasonably safe place to work unless the plaintiffs are granted leave to amend their complaint to allege a cause of action for negligence. If no claim of negligence is made, however, there would be no need to attempt to instruct the jury as to the relationship between that concept and unseaworthiness.

35. In Venable v. A/S Det Forenede Dampskibsselskab, 399 F.2d 347 (4th Cir. 1968), the case relied upon by the district court to support its charge, the Fourth Circuit stated that "operational negligence has been subsumed under the doctrine of unseaworthiness, and a trial court's instructions should no longer attempt to distinguish between the two." Id. at 351. Citing Mahnich and decisions of other circuits, the Venable court stated that a shipowner had an absolute duty to furnish a safe place to work. Usner clearly undercut the Venable assertion that operational negligence had been merged with unseaworthiness, a fact recognized by the Earles court. 486 F.2d at 1107 . However, it could be argued that Usner does not mandate a rejection of the Venable assertion that the duty to furnish a safe place to work is 